\title{
The Transformation of Leadership Style in Shaping the Character of World Class Navy Officer
}

\author{
Eko Setijo Pudjiantoro \\ Doctoral Program, Human Resource Management, State University of Jakarta \\ Jl. Rawamangun Muka, RT.11/RW.14, Rawamangun, Jakarta Timur, 13220 \\ Kasikurdikpa Subdiskurdik Disdikal Mabesal Cilangkap Jakarta Timur \\ E-mail: ekosp.12273p@gmail.com
}

\begin{abstract}
Faurna Luciani Pakpahan
Doctoral Program, Human Resource Management, State University of Jakarta

Jl. Rawamangun Muka, RT.11/RW.14, Rawamangun, Jakarta Timur, 13220

Kasubdis Garbia Disku Kolinlamil Jl. Raya Pelabuhan Pos IX Tanjung Priok

E-mail: lucianipapahan@gmail.com
\end{abstract}

Hady Efendy (Corresponding Author)

Education Practice and Academic Consultant

E-mail: efendy_hady@yahoo.co.id

Received: August 16, 2017 Accepted: August 31, 2017 Online published: September 22, 2017

doi:10.5296/ijhrs.v7i4.11712 URL: https://doi.org/10.5296/ijhrs.v7i4.11712

\begin{abstract}
Institutions of education (lemdik) the naval education and training command (kodiklatal) has the duty to organize doctrine and organization guidance in the ranks of the Indonesian National Army Navy (TNI AL) as well as the training and training of the navy in support of the Navy's role in forming officers navy. For that reason, the leadership style transformation commander navy training education can be used as a reference in motivating and encouraging his subordinates to work professionally in accordance with the duties and responsibilities. In the context of the process of education and training of navy officers, it has been from the
\end{abstract}


basic stage of military to the formation of officers that have been instilled in the attitude of loyalty, dedication and respect to senior officers or officers. Transformation of the leadership style of the commander the naval training commander should always be guided by the new spirit by the chief of staff of the navy to develop and develop new aspirations and passion for creative, innovative thinking and character as a naval officer the world class.

Keywords: Transformation style of leadership, character officer's navy, kodiklatal, lemdik, world class navy

\section{Introduction}

In era of globalization with the requirements of various competition is so tight, in an organization required a leader who is able to make a change and challenge to move towards the better. Kodiklatal lemdik as a place of crater of Candra Dimuka for officers of the navy has a role so great towards the creation of human resources of professional soldiers of the navy. The success of kodiklatal lemdik in forming the Indonesian Navy officers is supported by the existence of leadership style transformation in the process of education and training to shape the character and personality of the Indonesian Navy officers in facing the dynamics of the problems that arise in their assignment. Through education and training, the transfer of science and technology is given to the navy officers, of course, it cannot be separated from the role of transformation of senior officer leadership style that always provide guidance, encouragement and motivation to officers who follow education and training in kodiklatal.

Institutions of education (lemdik) the naval education and training command (kodiklat) has the duty to organize the guidance of doctrine and organization in the units of the Indonesian Navy and the training of education and training in order to support the task of the Indonesian Navy that plays a role in shaping officers of the Indonesia Navy. In the opinion of Hersey and Blanchard, in his book Miftah Thoha (2003), a leader is someone who can influence other people or groups to perform the maximum performance that has been established in accordance with the goals of the organization. The organization will run well if the leadership has skills in the field, and each leader has different leadership skills and styles. While subordinate is a person or group of people who are members of an association or followers who at all times ready to carry out orders or tasks that have been agreed together in order to achieve goals. In an organization, subordinates have a very strategic role, because the success or failure of a leader depends on his followers.

The transformation of leadership styles performed by commander kodiklatal greatly affect the survival of the organization being subordinated start kodiklatal staff commander, commander of education (Dankodik), commander of education center (Danpusdik) and commander of school (Dansekolah). Therefore, the leadership style of kodiklatal commander can be used as a reference in motivating and encouraging his subordinates to work professionally in accordance with their duties and responsibilities. In the context of the process of education and training of the Indonesian Navy officers, it has been from the basic stage of military to the formation of officers that have been instilled in the attitude of loyalty, dedication and respect to senior officers or officers. Positive values of the organization become an important foundation for building character for the officer of the Indonesian Navy, to always act in 
accordance with the norms and rules as a soldier who has the soul of Sapta Marga and Sumpah Prajurit. Thus, as a navy officer must have knowledge and skills and broad insight, thinking far ahead to face challenges in the era of globalization.

The leadership of the kodiklatal command leader's leadership style should always be guided by the new spirit by the chief of staff of the Indonesia Navy to develop and develop new aspirations and passion for creative, innovative thinking and character as a world-class navy officer. Thus the Indonesia Navy officers who attend education and training in kodiklatal must have the values of honor, honesty, sincerity, dedication, loyalty, professionalism and courage in supporting the development of the Indonesian Navy organisasi. Nevertheless, the transpormation of the leadership style that has been implemented in kodiklatal has issues to be faced, including:

a. How can the transformation of leadership styles in kodiklatal be best implemented especially in formulating the character of the Indonesian Navy officers?

b. How can the transformation of leadership styles in kodiklatal affect the character of the Indonesian Navy officers?

c. How is the implementation of leadership style transpormation in kodiklatal so that it can play a role to form the character of world class naval officer?

\section{Understanding Leadership Transformation}

Transformation is a gradual process of change so that it reaches the ultimate stage, a change made by responding to the influence of external and internal elements that will direct the change of a familiar form through repetitive multiplying or multiplying. In the opinion of the experts of leadership transformation can be defined as follows:

a. According to Bass (1998) in Swandari (2003), transformational leadership is a leader who has the power to influence subordinates in certain ways. With the application of subordinate transformational leadership will feel trusted, appreciated, and loyal and respect to the leadership. Eventually subordinates will be motivated to do more than expected.

b. According to O'Leary (2001) transformational leadership is a leadership style used by a manager if he or she wants a group to expand and perform beyond the status quo or achieve a whole new set of organizational goals. Transformational leadership in principle motivates subordinates to do better than what can be done, in other words can increase the confidence or self-confidence of subordinates that will affect the improvement of performance.

Based on the above opinion can be concluded that transformational leadership includes efforts to change subordinates to do more positive or better than what is commonly done that affect the improvement of performance. In the opinion of Richard L. Daff suggests that leadership style transfers are an influence of relationships between leaders and followers who intend to change and concrete results that reflect common goals. The definition includes seven essential elements in leadership, (1) leader, (2) influences (Influence), (3) Follower, (4) 
intention, (5) shared purpose (shared) Purpose), (6) Change (change), (7) Personal responsibility (Personal responbility).

\subsection{Understanding Character}

Personality experts have varying opinions about character terms etymologically. Of course the difference of view is based on the background of each discipline that is owned by these experts. Basically, character is an accumulation of the nature, character, and also the personality of a person. In addition to this understanding, there is a great deal of meaning of the word character expressed by the experts as follows:

a. Character is the real and different nature shown by the individual, a number of attributes that can be observed on the individual. According to Saunders these characters can be seen or observed because they are related to everyday life behaviors performed by each individual (W. Saunders, (1977: 126)).

b. Character is personality in terms of ethical or moral starting point, such as the honesty of a person, usually has a connection with the properties that are relatively fixed. Here he relates the character to the ethical standard - the moral of a person in the honest attitude of the individual or individual concerned. (Gulo W, (1982: 29)).

c. Character is psychological traits, morality or character that distinguishes one from another, character, and character. Here he refers to the inner beauty or attitudes of the heart-minded person who has a mental atmosphere, morals and manners or courtesy (Kamisa, (1997: 281)).

From the various definitions mentioned above, the definition of character is a series of attitudes, behaviors, motivations, and skills of a person formed from the internalization of virtues that are believed and used as a basis for Perspective, thinking, attitude, and acting, so that they can live and work together, both within the scope of family, society, nation and state.

For that, the character possessed by a person is basically formed through a fairly long learning process. Human character is not something that is born from birth. Moreover, the character is the formation or even the environment and also the people who are around the neighborhood. Character is formed through the learning process in several places, such as at home, school, and in the neighborhood around the residence. Parties that play an important role in the formation of a person's character is family, teachers, and peers.

\subsection{Understanding World Class Navy}

According to Alfret therapist Thayer Mahan (1840-1914), a US navy officer declared that whoever controlled the oceans would rule the world, the statement stated in his book: The Influence of Sea Power upon History (1660-1783) as an analysis of the influence of marine forces over the rise of many countries in the world. European countries, especially Britain, have a political policy to encourage its naval forces to carry out ocean exploration. At that time, the power of the British navy was a world-class navy all over the world.

History also notes that the great kingdoms of the archipelago, such as Sriwijaya, Majapahit 
and Demak, in its heyday once had a strong navy. The period of glory was slowly receding and reaching a nadir point when colonialism was present to divide the various kingdoms that existed. With the end of colonialism in the land of the earth in 1945, Indonesia as a new state attempted to build a state structure, including the components of defense. Understanding world class, according to the Merriam Webster Dictionary is the caliber or the highest level in the world. In the naval context as an organization that has the Main Equipment of Weapon System (Alutsista) and manned man, the world class navy can be referred to as a navy with equal ability and professionalism with advanced or modern state navies. Meanwhile, according to Kanter (2002), and gave birth to a social class with the ability to control resources, and operated far beyond the border and crossed into a wide area. Based on the above understanding, it can be concluded the definition of the world class navy is a navy that can bring power in various parts of the world.

In building world-class naval characters, the navy's human resources transformed into an intellectual soldier (scholar soldier) to manned the Indonesian Navy effectively and efficiently according to the technology they possess. In this way, the Indonesian Navy is able to project power to regions around the world according to Indonesia's national interests to enhance its role in the region and in the world to respond to dynamic maritime challenges. As a maritime sea state is a means that must be completely secured from all kinds of impending disruptions.

\subsection{Leadership Theories}

Leadership plays an important role in the implementation of change that involves two important aspects, namely change and people "change and people". Changing the real organization is about changing people's behavior, so the organization in carrying out change requires leaders, who can help spread and retain the new values needed for public sector reform. Therefore, it is necessary precision for a leader in dealing with change, especially in the era of globalization and the dimensions of environmental change today, for that below will be described leadership theories in the opinion of experts, as follows:

a. The Greatmen Theory. Based on the belief that the leader is an extraordinary person, born with innate qualities, destined to lead. Known figures are Napoleon, George Washington, or Martin Luther, who has had a major impact on society (Wart, 2003).

b. The Theory of Nature. According to Bolden, et al (2003) and Wart (2003), listed a series of traits or qualities associated with existing leadership in abundance and continue to be produced. All the traits that describe some of the attributes of human beings are positive or godly, the passion for life. Emphasis on individual traits (physical, personal, motivation, talent) and skills (communication and ability to influence) that accompany leaders to all leadership tasks.

c. Behavioral Theory. It concentrates on what leaders really do rather than the application of their quality. Different patterns of behavior are observed and categorized as leadership styles (Bolden et al., 2003). 
d. Situational Theory. This approach sees leadership as specific to situations in which leadership is underway. For example, some situations may require an autocratic style, and while others may need a more participatory approach. According to Papworth (2008) the most effective leadership style is determined by the degree of "preparedness" of leaders and followers.

e. Contingency Theory. This theory is a refinement from a situational point of view that focuses on identifying situational variables that most predict the most appropriate or effective leadership style to suit a given situation.

f. Transactional Theory. This approach emphasizes the importance of the relationship between leader and follower, focusing on the state of mutual benefit, this theory derives from a 'contract' form in which leaders provide things like rewards or recognition in return for the commitment or loyalty of followers.

g. Transformation Theory. The main concept in this theory is the change and role of leadership in imagining and implementing organizational performance transformation. Emphasis on leaders who make changes in the main structures, processes, or culture (Wart, 2003).

\section{Results and Discussion}

\subsection{Transformation of Leadership Style in Forming Character of the Indonesian Navy}

\section{Officer}

Leadership in the military is recognized as a benchmark for almost any leadership form ever undertaken, one reason is that the output of the military leadership process is life or death for the people it leads. The military is a strongly indoctrinated entity, which is implemented in the mindset, speech patterns, and patterns of its members in everyday life. Indoctrination stuck since a citizen (civilian) decides to become a military that will ultimately bear fruit in the form of posture and personal character, when he has graduated from education and effectively become a member of the military. Regardless of the universal norm in the doctrinal concept that applies to all soldiers, members of the military must still see the real world which in turn will force to think. The main doctrine he must face in the assignment of a military is to "kill or killed" his enemy, but also to "survive or die" by the changes taking place around him. This metamorphosis should be read and recognized by any current military leader, who likes or dislikes to shift the paradigm of military leadership in the future.

The style of leadership is an influence that departs from a belief formed from the loving and compassionate nature of each person. To be able to achieve that personal quality then the fundamental thing is to do the coaching and character building of each person personal of navy officers, a form of good personality and bad on each individual closely related to the leadership process will run. While all the good attitude will be used as a guide in the process of human interaction both in the military environment and in social as a social creature. Thus to be able to form a character of the navy officers who are reliable and qualified in the Indonesian Navy environment required leadership style of the Indonesian Navy officers who 
have good character, attitude, moral and ethics.

Likewise with the process of implementation of education and character development of the Indonesia Navy officers in kodiklatal, always implemented in stages and continuing. Where in the process of forming the character of the Indonesian Navy officers daily there is a senior officer or student counselor (Pabingsis) who always accompany in the education process, especially in dealing with student affairs. Pabingsis at kodiklatal has a dual function to the educational process that is First, as a value giver to each individual pasis, Second, role to give encouragement and motivation to life pasis during in educational institution. As a course of course, during the course of education will get the duties and obligations so much that the level of saturation and boredom will definitely be faced, that is where the role of Pabingsis as a senior officer is needed.

Transformation of leadership style in kodiklatal adapted to the educational programs are carried from the First Education Officer (Dikmapa), Educational Establishment Officer (Diktukpa), Specialization Education Officers (Dikspespa) and Further Education Officers (Diklapa). All educational programs are already entered into the Education Plan (Rendik) navy which annually will be addressed through the stages and planning. While kodiklatal as educational institutions will be instrumental in print and mendidikan navy officer to be a reliable and professional as needed expected. Professional capabilities of the soldiers can be achieved through the development of integrated and continuous, ie "development that is based on the philosophy:" Dwi Warna Purwa Cendikia Wusana "which means that in addition to forming a soldier of Sapta Marga formidable, also has a professional naval skilled and proficient in their duties and have a high physical qualities.

\subsection{Character Building and Ethics of the Indonesian Navy Officers in Kodiklatal}

In the life of The Indonesian Navy officers it is necessary to have a recognized positive character and can be followed by followers or subordinates. Characters are given by leaders to form the ethical and moral values that a person embraces to behave well. Character is the energy that comes from within the person of the leader to judge something right and wrong, which is related to knowledge to determine attitudes and actions. Character gives strength and courage to do the best and right in an uncertain environment. The formation of character is the dominant element to be able to build the identity of an officer of the navy. In fact, the process of formation, development and character development for the Indonesian Navy officers at this time is still not optimal so that the need for education on the formation of the character of the Indonesia Navy officers who entered to follow the education in lemdik kodiklatal.

Hard work needs to be done in the formation of the character of the Indonesian Navy officers, because the process of building character is like sculpt or shaping the soul in such a way, so it is unique/interesting and can be distinguished with others, but in accordance with the interests of the organization. Character formation is a complex process that can be done through education and training in the kodiklatal lemdik continuously over a period of time. Another thing that is still constrained in realizing the formation of the character of the Indonesian Navy officers is a mistake in the recruitment process of candidate officers which resulted in 
the acceptance of candidate officers who do not have character in accordance with the standards. Similarly, efforts to coaching and development of characters that have not been integrated and comprehensive will weaken the character possessed.

However, in the formation of characters for navy officers cannot be done instantly or quickly, it must go through a long process, meticulous and systematic. The need for guidance and training programmed and planned in accordance with the learning activities that are implemented in lemdik kodiklatal. Therefore, the character education quality standards that need to be applied to the development and character development of navy officers in kodiklatal, which according to Peterson and Seligman (2004) there are 6 virtues in the formation of characters, among others:

1. Wisdom and Knowledge. Wisdom and knowledge are cognitive forces that require the skills and use of knowledge.

2. Determination. Persistence is the emotional forces that involve the counselor's will to accomplish goals in the face of the opposite, external or internal.

3. Humanity. Humanity is the interpersonal forces that involve caring for and protecting others.

4. Justice. Justice is the power of citizenship that underlies the life of a healthy society.

5. Simplicity. Simplicity is the forces that guard against excessive deeds.

6. Transcendent. Transcendent are the forces that foster relationships to the wider universe and give meaning.

Educational methods applied in lemdik kodiklatal consists of teaching methods that are academic in the form of provision of learning materials in the form of science and skills that carried out learning in the classroom. For practical training activities is provided by using the application of education methods in the field of activities that prioritize the debriefing practices as will be encountered in the field of assignment. While the additional provision of physical skills development by prioritizing aspects in the military field with methods that are mentoring and nurture in the form of teaching on mental, moral, behavior, code of ethics, procedures, leadership and character formation as a the Indonesian Navy officer.

The success of participants in following education in kodiklatal is characterized by the ability to adapt to the environment, whether in the form of academic and non-academic demands. The military-based educational environment conditions contained in kodiklatal require that each passage exercise every rule, order, and demands. The demands imposed on the participants in the following education and training, among others: First, the fulfillment of academic values in the form of values in following the lesson in the class, Second, the fulfillment of personality values in the form of assessment of everyday behavior during the education, third, The value of healthy in the form of physical fitness value both at the beginning and end of education. For additional programs that are not less important are the learning of the military sciences applied in the learning activities outside the classroom in the form of marching rules, the use of physical attributes, codes of ethics, morals, mental 
guidance and military procedures containing elements in it in the form of leadership character formation as Indonesian Navy officer.

In the process of forming the character of the Indonesian Navy officers cannot walk away, however, it is necessary for senior officers who always control and accompany and provide advice in acting when the participants faced the problem. All cannot be separated from the activities of guidance and care for the learning process that has been implemented in lemdik kodiklatal, as an officer of the Indonesian Navy can be said to have a good character when in private the Indonesian Navy officers ready exits in "Sumpah Prajurit" and "Tri Sila" of the Indonesian Navy so it will not violate the rules and norms outlined by the Indonesian Army / Indonesian Navy both during their education and after serving in their units.

\subsection{Implementation of Leadership Transformation Style in Shaping the Character of World Class of the Inndonesian Navy Officers}

In facing the challenges of the development of such a dynamic strategic environment and the era of rapidly growing globalization, it takes the navy officers who have high integrity, maritime vision, and insightful nationality and love the country. In addition, navy officers must be professionals with high intellectual and academic ability, as navy officers must have extensive knowledge and knowledge and intellectual ability in all their activities, either through education and training activities in lemdik kodiklatal internal as well as joint training activities carried out between the Indonesian Navy and the navy of countries in the world. As conveyed by navy staff commander on the anniversary of the Indonesian Navy in kodiklatal 2016, "As a Indonesian Navy officer must have strong character and high individual motivation to always give the best work for the nation and country. Therefore, the Indonesian Navy officer must have a strong desire and willingness to always fill up by continuing to improve skills in all fields. Not only limited to the field of defense science alone, but need to understand various other disciplines without excluding the marine profession.

Kodiklatal as one of the educational institutions in the ranks of the Indonesian Navy, must be able to realize the aspirations that have been conveyed by the Indonesian Navy leader by doing efforts to improve, improve the quality, and educational feasibility, so that the expected target can be achieved, that is as from the effort to realize a world class of the Indonesian Navy or world class navy. However, efforts made by lemdik kodiklatal must be in line with the roles of the Indonesian Navy in upholding peace in the territorial waters of The United State of The Indonesia Republic (NKRI). Kodiklatal must be able to produce the Indonesian Navy officers, especially in manning the Indonesian Navy weaponry, namely Warship of the Republic of Indonesia (KRI), aircraft, marine combat equipment and troops. As for diplomacy activities abroad, the Indonesian Navy officers who have completed education and training in kodiklat can be sent to support UN forces in maintaining peace and security in the world, both with KRI and troops.

Through the transformation of leadership style then the process of formation of the character of the world class officer of the Indonesian Navy is carried out in kodiklatal which in the implementation can be accounted for through the tasks of security of the territorial waters of the Republic of Indonesia has 3 (three) important roles, among others: 
a. Military/Defence. The military role of the navy is implemented in the framework of upholding the sovereignty of the state at sea by means of state defence and deterrence, preparing forces for war preparation, warding off any military threats by sea, maintaining maritime stability, protecting and maintaining sea borders with neighbouring countries.

b. The Police (Constabulary) Role. The role of the Indonesian Navy Police Force is implemented in the context of upholding the law at sea, protecting national marine resources and wealth, maintaining order at sea, and supporting nation building, in this case contributing to stability and national development.

c. The Role of Diplomacy Support. The Role of Diplomacy Support by the Indonesian Navy is a very important role as does every navy in the world. This role was once known as a show of naval power that has become the traditional role of the navy.

d. Other Roles. In addition to the above three roles, the Indonesian Navy also has a role that is not less important is the role to perform operations other than the war (Military Operations Other Than War) in order to exploit the power of the Indonesian Navy for the benefit of the nation and state.

With the above explanation, then kodiklatal in conducting education and training should be able to make improvements, especially related to the preparation of facilities and infrastructure used for the learning process, both in the process of learning in the classroom or during practice in the field. Of course, everything is supported by the transformation of leadership style of a commander of kodiklatal who always provide support and motivation to the Indonesian Navy officers in the field so that all the duties and responsibilities can run smoothly and problems that appear can be resolved with the best.

The transpormation of a positive leadership style in Kodiklatal then the resulting impact will create the character of military officers who are professional and world-class. For that, in the era of globalization that occurs today the benefits of the Indonesian nation when it has a professional and world-class the Indonesian Navy, among others:

a. First, increase the deterrent effect that makes other countries think further before showing their intention to confront directly and openly.

b. Second, build and gain the trust of the international community. Community trust can be gained as a consequence of active participation and involvement in various international sphere activities such as peacekeeping operations, peace-building operations, peacekeeping operations, maritime security operations and other confidence building measures activities.

c. Third, increase the bargaining position of the country in various efforts to resolve regional and international issues as an integral part of government diplomacy and the implementation of foreign policy.

d. Fourth, securing national interests in and outside the region, world-class navies with advantages possessed will be able to project their strengths when national interests at sea require security guarantees, either through day-to-day operations, special security operations or missions of multinational operations outside the region . 


\section{Conclusion}

To form the character of the navy officers who have the quality and quantity required a leader who has a fair, honest, kind and open nature. The personal qualities of the leader will grow and develop and have no difficulty in interacting with the family and the surrounding environment.

As an officer of the navy can be said to have a good character when in private the Indonesian Navy officers already exist in "Sumpah Prajurit" and "Tri Sila" of navy so it will not violate the rules and norms laid down in by the Indonesian Army / Navy both during the education and after serving in his unit.

Kodiklatal as one of the educational institutions in the ranks of the navy, must be able to realize the aspirations that have been conveyed by the navy leader by doing efforts to improve, improve the quality, and educational feasibility, so that the expected target can be achieved, that is as from the effort to realize the world class navy.

\section{Recommendation}

Kodiklatal as one of the education institutions within the Indonesian Navy, should always be consistent in shaping the character of the Indonesian Navy officers, because each individual and individual will have different personal, background and nature.

Kodiklatal in forming the character of the Indonesian Navy officers, should always be guided by theories of leadership that can provide motivation, encouragement and aspiration in forming a person who has quality that guided sapta marga, sumpah prajurit and tri sila.

Kodiklatal in forming the character of the world class officer of the Indonesian Navy, should complement the supporting components in the process of learning activities. Components in the form of facilities and infrastructure that exist in lemdik kodiklatal.

\section{References}

Amarulla Octavian. (2012). Militer dan Globalisasi: Studio Sosiologi Militer Dalam Kontek Globalisasi dan Kontribusinya Bagi Transpormasi TNI. Cetakan Kedua. UI Press Jakarta.

DR Marsetio. (2014). Sea Power Indonesia. Cetakan Pertama. Universitas Pertahanan Jakarta. PT. Sukarta \& Sukarya Pandetama.

DR Marsetio. (2014). TNI Angkatan Laut Berkelas Dunia: Paradigma Baru. Cetakan Kedua, Maskas Besar TNI AL.

Kepala Staf Angkatan Laut, Bapak Laksamana TNI Ade Supandi, S.E., M.AP. (2016). Pidato HUT AAL di Bumimoro Krembangan Surabaya. Majalah Cakrawala.

Peraturan Kasal Nomor Perkasal Nomor 5 Tahum 2016, tanggal 26 April 2016 tentang Kebijakan Dasar Pembangunan TNI AL Menuju Kekuatan Pokok Minimum (Minimum Essential Force). Markas Besal Angkatan Laut.

Peterson, C., \& Seligman, M.E.P. (2004). Character Strengths and Virtues: A Handbook and 
Classification. New York: Oxford University Press.

\section{Copyright Disclaimer}

Copyright for this article is retained by the author(s), with first publication rights granted to the journal.

This is an open-access article distributed under the terms and conditions of the Creative Commons Attribution license (http://creativecommons.org/licenses/by/4.0/). 